\title{
STRA6 wt Allele
}

National Cancer Institute

\section{Source}

National Cancer Institute. STRA6 wt Allele. NCI Thesaurus. Code C104694.

Human ST RA6 wild-type allele is located in the vicinity of 15q24.1 and is approximately 33 $\mathrm{kb}$ in length. This allele, which encodes stimulated by retinoic acid gene 6 protein homolog, plays a role in both retinol metabolism and organ development. Mutation of the gene is associated with both syndromic microphthalmia type 9 and isolated colobomatous microphthalmia. 